\title{
Usage Pattern of Smartphone during COVID-19 Lock Down
}

\author{
Diksha Gautam $^{1 *}$ and Minakshi Gautam² \\ ${ }^{1}$ Department of Family Resource Management \& Consumer Science, College of Community \\ Science, A.N.D.U.A.\&T., Kumarganj, Ayodhya, Uttar Pradesh \\ ${ }^{2}$ Department of Extension Education and Communication Management, College of \\ Community Science, Punjab Agricultural University, Ludhiana, Punjab, India \\ *Corresponding author
}

Keywords

Smartphone,

Pandemic,

Lockdown,

Smartphone usage,

Life style

Article Info

Accepted:

10 November 2020

Available Online:

10 December 2020
A B S T R A C T

The spread of COVID-19 has prompted people all over the world to change their daily lives and, in many cases, work or study from home, Changes in behaviour due to lockdown restrictions have caused measurable changes in the usage of Smartphone. The main aim of this study was designed to study usage Pattern of Smartphone during COVID-19 Lock down. Online survey was conducted in about 200 respondents in the age group of 18 - above 30 years. Questionnaire based online survey showed that Total 80 percent respondents experiencing increased usage of Smartphone mainly for social media and entertainment purpose daily. Due to longer usage of Smartphone 21 percent of respondents' experienced visual fatigue and 18 percent experienced watery eyes. These changes in Smartphone use might have long lasting effect on physical, mental and social health and need corrective measures to help people lead a healthy lifestyle during this epidemic and in future.

\section{Introduction}

With the rapid spread of corona virus across the world, the Covid- 19 cases are progressively increasing and Governments of each country have imposed lockdown at different intervals across the globe to ensure social distancing, apart from maintaining personal hygiene, as it is the only way to limit the spread. The Covid-19 spread gives the feeling of fear in public for not going out from their home until any emergency. This situation brings people in concern of their health in priority basis. There are lot of challenges that we are facing due to this pandemic but the technologies give their rich contribution to help us in this tough time to live the life in far better conditions and 
somehow made us able to survive in our home without going out. In this technological era, we are surrounded with various technologies but the Smartphone is the most closed technology for every age group in this time of pandemic because we are dependent on it for almost every work either it may be work from home, communication through social media, online ordering of groceries, health related apps for covid-19 alert and many more. There are drastic changes that people are experiencing in their lifestyle in every aspect of life like education, jobs, shopping, tourism, entertainment any almost everything. It is an unprecedented experience, where people have had to stop abruptly from their routine and busy lifestyles, with a lot of time at their disposal, confined to homes, as most of them work from home while the others have closed down.

Without a Smartphone, one feels incomplete and it has become need of the hour, especially with the Covid-19 pandemic quarantine. The social distancing that stemmed as a result of Covid-19 has spiked Smartphone usage among various categories of people, the college students or business/ employed persons who are attached to their Smartphone even otherwise. People can remain in touch and get updates on every development in all walks of life during the pandemic, within no time. Smartphone was always a good companion for all time but in this pandemic we are dependent for it more than normal. So the present study was designed to focus on the increased usage of Smartphone among various age groups during this covid 19 lockdown.

\section{Materials and Methods}

Total 200 respondents in the age group of 18 to above 30 years were selected randomly from the different part of Uttar Pradesh. A simple and short time-consuming online survey was done through self structured questionnaire. All the data for fulfilment of objective of the study was collected safely from respondents. Data analysis was done by calculating frequency and percentage.

\section{Results and Discussion}

Findings of the study were concluded under following heads:

Demographic Profile of the respondents (Table 1)

Usage Pattern of Smartphone during lockdown (Table 2)

\section{Demographic profile of the respondents}

Majority of respondents i.e. 7.8 percent were female and 22 percent were male. Majority of respondents i.e. 34 percent were in the age group of 18-21 years followed by 30 percent in 26-30 years, 25 percent were in above 30.majority of respondents were students followed by employed 32.5 percent. Majority of respondents were living in urban area and in nuclear family.

\section{Usage pattern of smartphone}

In the usage pattern of Smartphone, one third of the respondents were using Smartphone since last 3 years. 80 percent respondents agreed that Smartphone usage has increased during lockdown. Pietrobelli et al., (2020) also found in their study that Screen time increased by 4.85 (SD 2.40) h/d (P < 0.001). Before lockdown majority of respondents used the Smartphone 3-4 hours per day and 37 percent agreed that more than 3 hours usage has increased per day. About one third respondents said that Social media usage time via Smartphone is increased from $1 / 2$ to 2 hours more than normal.

Some statement regarding Smartphone and usage were also asked to the respondents, as 
per their response majority of respondents agreed that Smartphone was increased during lockdown for safety instruction, Covid 19 alerts, work from home and spending quality time during lockdown. The responses indicated that Smartphone was easy to use best companion for the users for various daily activities during this pandemic.

When asked to the respondents about increased interaction during lock down majority of respondents i.e. 73.5 percent agreed that interaction with their friends and 70.5 percent agreed for interaction with family followed by 45 percent agree for relatives and 52 percent to teachers for online studies.

The figure 1 shows that majority of respondents used their Smartphone mainly for social media followed by Entertainment and online classes. Shabir (2019) also found that Smartphone can offer a overabundance of information resources within the palm of a person's hand and also filled the communication gap via social networking sites especially in this current setting. In the time of Covid 19 lockdown 79 percent respondents stay connected to their Smartphone for news and alerts and 76.2 percent respondents utilized their Smartphone for learning new thing/hobbies during lockdown (Fig. 2).

In the figure 3 the symptoms reported by respondents due to excess use of Smartphone during lockdown period. 21 percent of respondents experienced visual fatigue followed by watery eyes 18 percent, burning sensation 16 percent, Dry eye and blurred vision 11 and 10 percent respectively. Gautam (2018) also found in their study that visual fatigue was also experienced when respondents used their Smartphone for longer period daily (Table 3).

Table.1 Distribution of the respondents on the basis of demographic profile

\begin{tabular}{|c|c|c|c|}
\hline S.No. & & & Percentage \\
\hline \multirow{2}{*}{1.} & \multirow{2}{*}{ Sex } & Female & 78 \\
\hline & & Male & 22 \\
\hline \multirow[t]{4}{*}{2.} & \multirow[t]{4}{*}{ Age group } & 18-21 years & 34 \\
\hline & & $22-25$ years & 11.0 \\
\hline & & 26-30 years & 30.0 \\
\hline & & Above 30 & 25.0 \\
\hline \multirow[t]{4}{*}{3.} & \multirow[t]{4}{*}{ Occupation } & Student & 56.5 \\
\hline & & Employed (Self/ Government) & 32.5 \\
\hline & & Unemployed & 5.5 \\
\hline & & Others & 5.5 \\
\hline \multirow[t]{3}{*}{4.} & \multirow{3}{*}{$\begin{array}{l}\text { Residential } \\
\text { area of house }\end{array}$} & Urban & 47.0 \\
\hline & & Semi Urban & 33.0 \\
\hline & & Rural & 20.0 \\
\hline \multirow[t]{2}{*}{5.} & \multirow[t]{2}{*}{ Family Type } & Nuclear & 70.0 \\
\hline & & Joint & 30.0 \\
\hline
\end{tabular}


Table.2 Distribution of respondents on the basis of usage pattern of smartphone

\begin{tabular}{|c|c|c|c|}
\hline S.No. & & & Percentage \\
\hline \multirow[t]{4}{*}{1.} & \multirow[t]{4}{*}{ Using Smartphone since } & Last 6 months & 3.5 \\
\hline & & Last 1 year & 5.0 \\
\hline & & Last 2-3 years & 16.5 \\
\hline & & More than 3 years & 75 \\
\hline \multirow[t]{3}{*}{2.} & \multirow{3}{*}{$\begin{array}{l}\text { Smartphone usage time increased } \\
\text { during lock down }\end{array}$} & Yes & 80 \\
\hline & & No & 10.5 \\
\hline & & Maybe & 9.5 \\
\hline \multirow[t]{4}{*}{3.} & \multirow{4}{*}{$\begin{array}{l}\text { Before lockdown Smartphone usage } \\
\text { time per day }\end{array}$} & $1-2$ hours & 27.5 \\
\hline & & 3-4 hours & 55.5 \\
\hline & & 5-6 hours & 10.5 \\
\hline & & More than 6 hours & 6.5 \\
\hline \multirow[t]{4}{*}{4.} & \multirow{4}{*}{$\begin{array}{l}\text { Smartphone usage time increased up } \\
\text { to }\end{array}$} & 1 hours & 20.0 \\
\hline & & 2 hours & 12.5 \\
\hline & & 3 hours & 30.5 \\
\hline & & More than 3 hours & 37.0 \\
\hline \multirow[t]{4}{*}{5.} & \multirow{4}{*}{$\begin{array}{l}\text { Social media usage time increased } \\
\text { via Smartphone }\end{array}$} & $1 / 2$ hour more than normal & 20.5 \\
\hline & & 1 hours more than normal & 25.5 \\
\hline & & 2 hours more than normal & 28.5 \\
\hline & & No change & 25.5 \\
\hline
\end{tabular}

Table.3 Responses of the respondents for smartphone usage during lockdown

\begin{tabular}{|c|c|c|c|c|}
\hline S.No. & Statement & Yes & No & Maybe \\
\hline 1. & $\begin{array}{l}\text { Smartphone is helpful in this lock down period } \\
\text { to follow the safety measures and instructions } \\
\text { announced by government. }\end{array}$ & 121 & 4 & 18 \\
\hline 2. & Fulfilled hobbies via Smartphone in lockdown. & 88 & 25 & 18 \\
\hline 3. & $\begin{array}{l}\text { Installed new apps in Smartphone during lock } \\
\text { down. }\end{array}$ & 118 & 23 & 2 \\
\hline 4. & Smartphone used for Covid-19 Alerts. & 115 & 16 & 10 \\
\hline 5. & $\begin{array}{l}\text { Smartphone use was the only time pass during } \\
\text { lockdown. }\end{array}$ & 36 & 100 & 5 \\
\hline 6. & Smartphone usage affected sleep. & 41 & 79 & 21 \\
\hline 7. & You felt anxious when internet slows down. & 76 & 53 & 13 \\
\hline 8. & $\begin{array}{l}\text { Dependency for work has been increased on } \\
\text { Smartphone during lock down period. }\end{array}$ & 112 & 23 & 7 \\
\hline 9. & Smartphone is your best companion. & 65 & 49 & 28 \\
\hline 10. & $\begin{array}{l}\text { Spending time at home during lock down was } \\
\text { easy with the help of Smartphone. }\end{array}$ & 99 & 19 & 24 \\
\hline
\end{tabular}


Fig.1 Distribution of respondents on the basis of interaction increased via smartphone during lock down

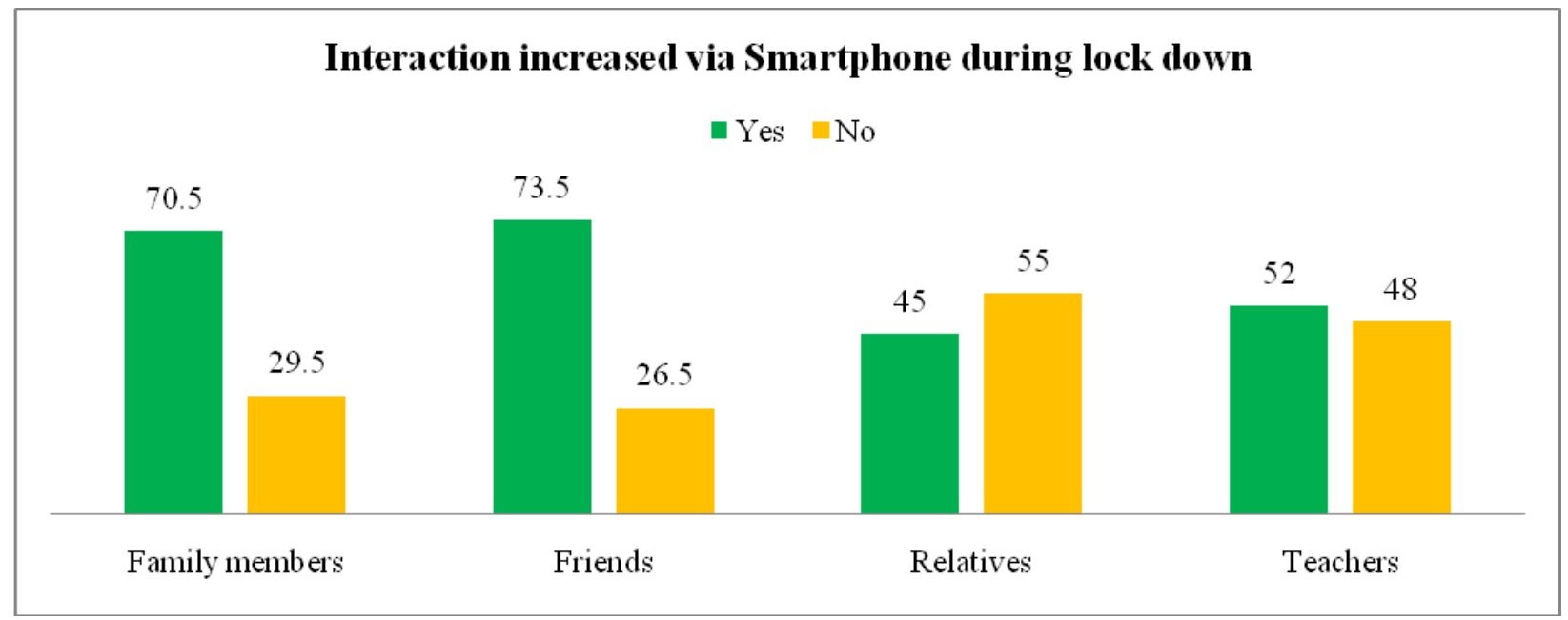

Fig.2 Distribution of respondents for smartphone use for various purposes

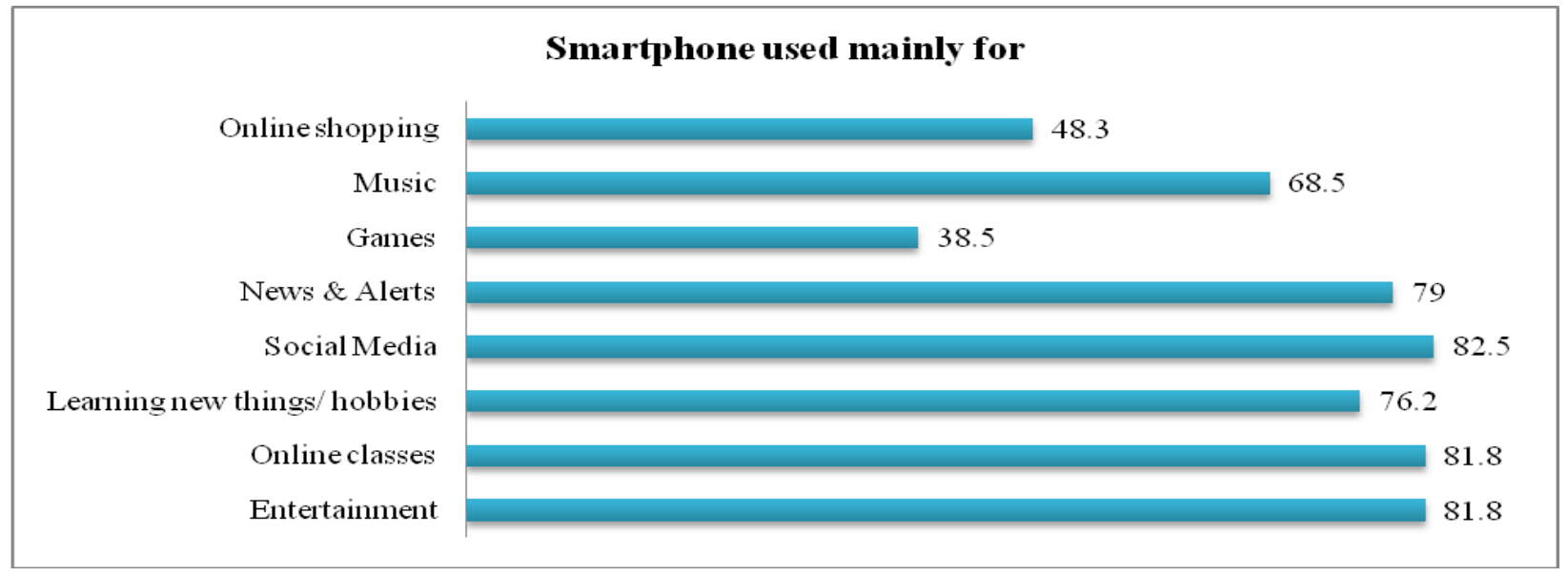

Fig.3 Symptoms that respondents experienced while smartphone use for longer duration

\section{Symptoms while Smartphone use for longer duration}

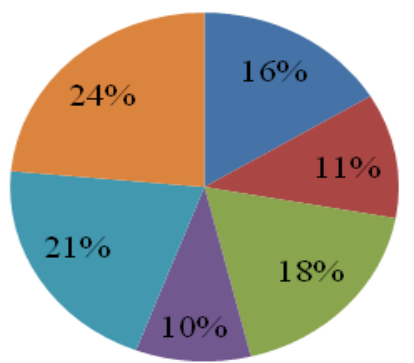

- Burning sensation

- Dry eyes

Watery eyes

Blurred vision

- Visual fatigue

None of the above 
In conclusion, smartphone is a boon if it is used wisely or smartly it has various negative effects too when used for longer time, it may postural or psychological. As every technology Smartphone also has its pro and cons. Smartphone makes learning cheaper, faster and easily accessible, with flexibility to time and place, eliminating the doubts of students and boost the learning process as additional and supporting teaching aids. It is the combined source of entertainment, shopping and connectivity for engaging us all the time. The impulsive use of Smartphone for entertainment purpose is unfortunately accompanied by negative consequences related to security and health problems. The excessive Smartphone usage during the pandemic accompanies the heightened risks of various health problems including psychological problems, cybercrime in the last month. The contributing factors for health related problems are basically lack of awareness.

\section{References}

Gautam D. (2018) Psychological Assessment and Postural Analysis of Smartphone Users (Unpublished doctoral thesis), G.B.P.U.A.T, Pantnagar, Uttarakhand

Kadeswaran, S., Brindha, D. \& Jayaseelan, R. (2020). Covid-19 lockdown and Smartphone usage, Education or Entertainment among Medical, Engineering and Arts Students. In Z. B. Shaik (Ed.) Covid 19 and Its Impact by Lockdown (pp. 15-33). Tamilnadu, India: ESN Publications

Shabir, R., and Mudasir, R., (2019). Impact of Smartphones on Young Generation. Library Philosophy and Practice.

Pietrobelli, A., Pecoraro1, L., Ferruzzi1, A., Heo, M., Faith, M., Zoller, T., Antoniazzi1, F., Piacentini, G., Fearnbach, S. N. and Heymsfield, S. B. 2020. Lockdown Effects on Lifestyle Behaviors, Obesity, Vol 28 (8):13821385.

\section{How to cite this article:}

Diksha Gautam and Minakshi Gautam. 2020. Usage Pattern of Smartphone during COVID-19 Lock Down. Int.J.Curr.Microbiol.App.Sci. 9(12): 966-971. doi: https://doi.org/10.20546/ijcmas.2020.912.117 